\title{
Deconditioning the athletic heart
}

\section{Andrew R J Mitchell, Hamish I MacLachlan, Pierre Le Page}

Department of Cardiology, Jersey General Hospital, Jersey, Channel Islands

\section{Correspondence to}

Dr Andrew R J Mitchell, mail@jerseycardiologist.com

\section{DESCRIPTION}

A 42-year-old competitive runner was referred for cardiac screening following the death of one of his running partners from a cardiomyopathy. He had no significant cardiac symptoms and there was no family history of a cardiomyopathy. Baseline ECG and echocardiography were abnormal with deep T-wave inversion in leads V1-V3 (figure 1A), mild left ventricular septal hypertrophy $(14 \mathrm{~mm})$ with normal cavity dimensions (figure $1 \mathrm{~B}$ and video 1 ). Hypertrophic cardiomyopathy was suspected. Cardiac MRI, however, showed no significant abnormalities and genetic testing was negative for common mutations.

A period of detraining was recommended, during this time he did not take part in physical exercise. After 3 months the investigations were repeated. The ECG (figure 1C) and echocardiogram had now normalised (figure $1 \mathrm{D}$ and video 2 ) with no evidence of ventricular hypertrophy. A diagnosis of an athletic heart was made and he was permitted to continue competition. Repeat investigations 9 months later revealed a return to baseline findings.
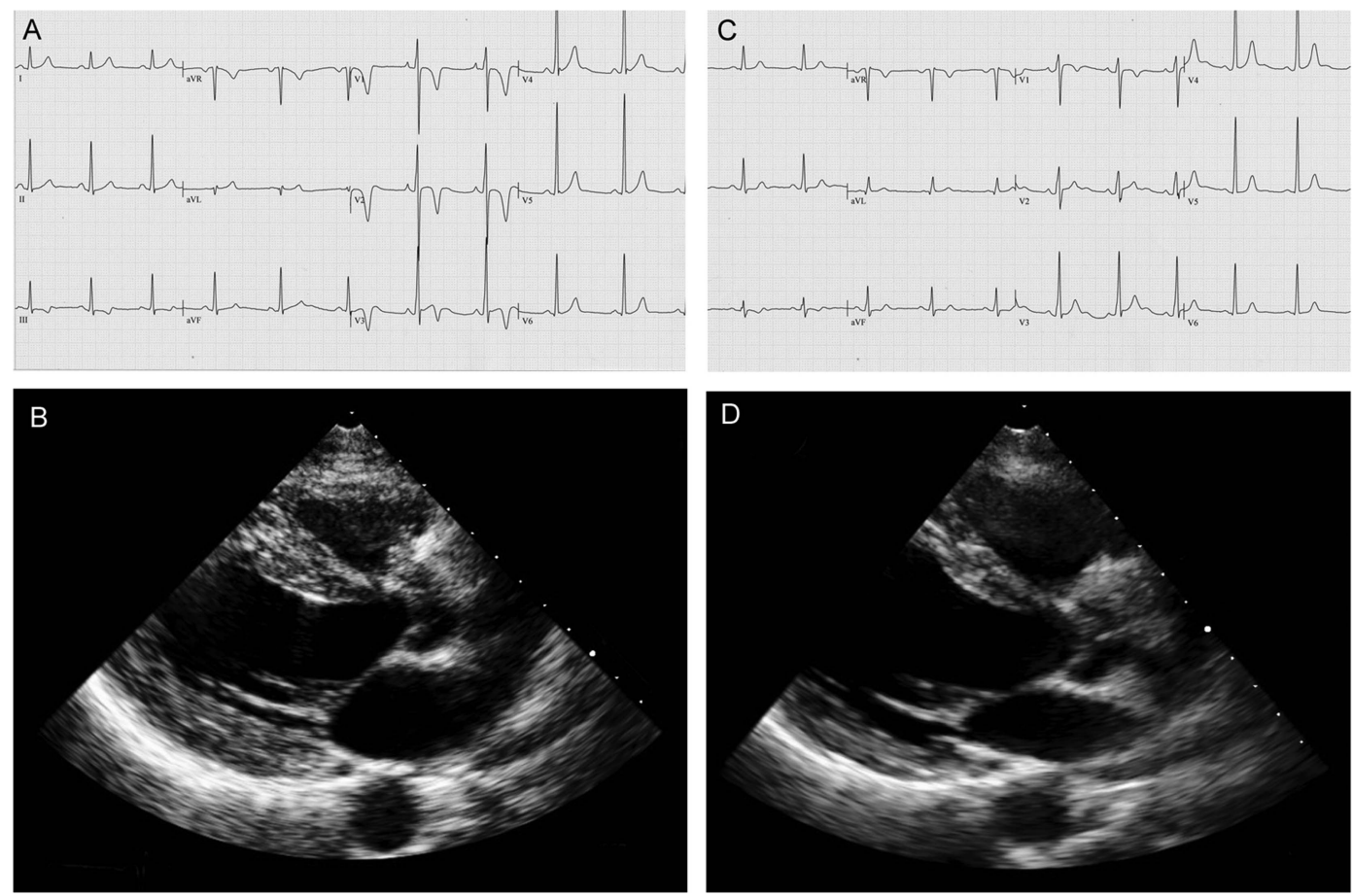

Figure 1 (A) Baseline ECG. (B) Baseline echocardiogram. (C) ECG after detraining. (D) Echocardiogram after detraining.

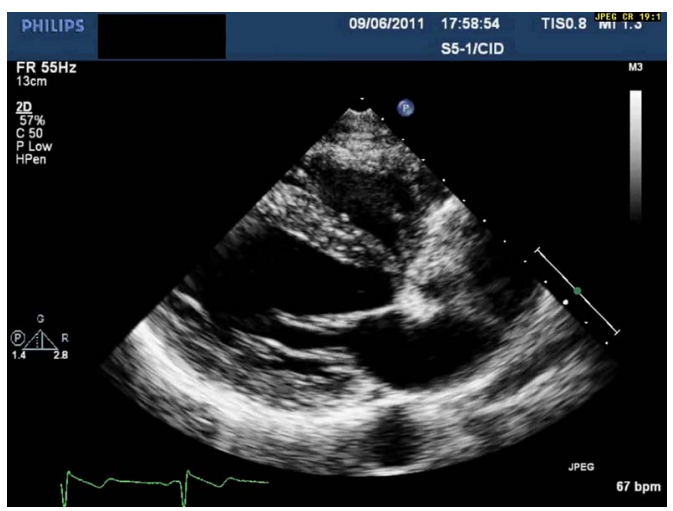

Video 1 Baseline echocardiogram.

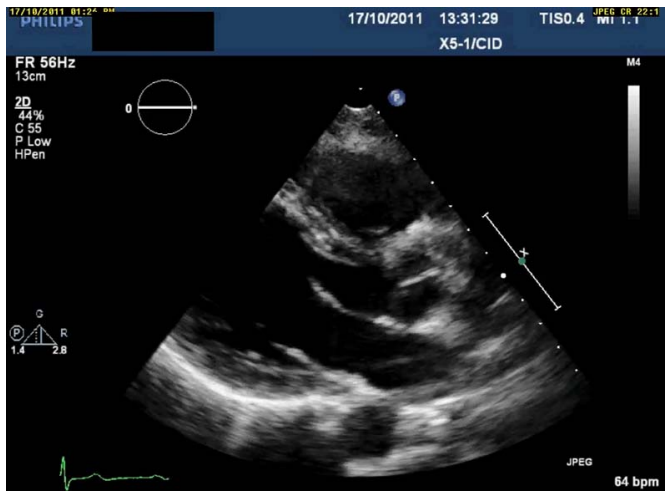

Video 2 Echocardiogram after detraining. 


\section{Learning points}

- Cardiac changes from prolonged athletic training can appear similar to those of a cardiomyopathy.

- After a long period of de-training, these changes should revert to normal.

- There may also be an overlap state with training bringing out the phenotype of a cardiomyopathy - surveillance may be warranted.
Preparticipation heart screening will detect abnormalities in athletes that may be suggestive of an underlying cardiac abnormality. Detraining can be extremely helpful in borderline cases when differentiating between an athletic heart and a cardiomyopathy.

Competing interests None.

Patient consent Obtained.

Provenance and peer review Not commissioned; externally peer reviewed.

Copyright 2013 BMJ Publishing Group. All rights reserved. For permission to reuse any of this content visit http://group.bmj.com/group/rights-licensing/permissions.

BMJ Case Report Fellows may re-use this article for personal use and teaching without any further permission.

Become a Fellow of BMJ Case Reports today and you can:

- Submit as many cases as you like

- Enjoy fast sympathetic peer review and rapid publication of accepted articles

- Access all the published articles

- Re-use any of the published material for personal use and teaching without further permission

For information on Institutional Fellowships contact consortiasales@bmjgroup.com

Visit casereports.bmj.com for more articles like this and to become a Fellow 